\section{Inspirerende om grunnleggende opplevelser}

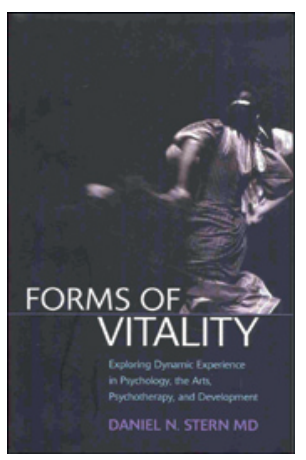

Daniel N. Stern

Forms of vitality

Exploring dynamic experience in psychology, the arts, psychotherapy, and development. 192 s. Oxford: Oxford University Press, 2010. Pris GBP 20 ISBN 978-0-19-958606-6

Psykiateren Daniel Stern (f. 1934) er kjent for å ha bidratt til nye utviklingspsykologiske modeller med utgangspunkt i nyere spedbarnsforskning.

I den første delen introduserer forfatteren temaet «vitalitetsformer» fra ulike vinkler: klargjøring av begreper med utgangspunkt i ulike psykologiske modeller og tidligere begreper, i tillegg til et blikk inn i hva nyere nevrovitenskap kan bidra med for å forklare fenomenene.

Forfatteren er opptatt av grunnleggende opplevelser som motivasjon, andres intensjoner og opplevelser som ligger under andre følelser - at følelser kan ha kvaliteter som at de vokser eller avtar i styrke, at de kan være pulserende, oppleves som avslappende eller oppildnende, akselererende eller deselererende osv. Videre er han opptatt av hvordan vi oppfatter disse nonverbale sanseopplevelsene både fra signaler fra egen kropp og i møte med andre.

I del to beskriver forfatteren hvordan vitalitetsformer i musikk, dans, teater og film bruker kunnskapen om vitalitetsaffekter bevisst for å fange vår oppmerksomhet og gi oss gitte opplevelser. Han beskriver hvilke måter de har for å beskrive og gi føringer fra kunstneren til utøveren. Det blir tankevekkende at vi har så lite språk om disse fenomenene innen psykologi og psykiatri.

I den siste delen ser forfatteren på utviklingsmessige og terapeutiske konsekvenser av kunnskapen.

Man blir imponert over hvordan Stern fortsatt, i hvert fall så langt jeg kan bedømme, holder seg orientert i den nevrobiologiske forskningsfronten og fortsetter å lage broer til andre kunnskapsområder som kultur og sitt eget fag: psykiatri og psykologi. Til tross for krevende temaer er hans engelsk tilgjengelig og relativt lettlest.

Det å få et utvidet språk på disse områdene er svært spennende av flere grunner: For det første oppleves begrepene som logiske og gjenkjennbare med henblikk på de opplevelsene man har som menneske. Man kan kjenne igjen de ulike kvalitetene av at det stormer innvendig uten sikkert å vite om det er hat, sinne, redsel eller fortvilelse. For det andre gir begrepene god mening i omgang særlig med ungdom. Nærmest daglig opplever jeg, både som tenåringsmor og ungdomspsykiater, at vi voksne skulle ønske at ungdommen kunne $s i$ hva som er galt, men at de ikke «lystrer». Vi voksne kan oppleve dette som motvilje, men med Sterns begreper i hu, kan vi tenke at de sterke opplevelsene ungdommene har, ikke er konkrete følelser, men mer underliggende vitalitetskvaliteter.

De to første delene er svært opplysende og inspirerende og bygger kanskje opp vel store forventninger til siste del, særlig til kapitlet Terapeutiske konsekvenser. Her hadde jeg ønsket meg flere eksempler og oppskrifter. Det synes som om Sterns terapeutiske eksempler er hentet fra mer nevrotiske tilstander, der det kan være om å gjøre å øke vitalitet, mens man blir nysgjerrig på hvordan han ville møtt pasienter med «vitalitet på avveie», som man kan se ved $\mathrm{AD} / \mathrm{HD}$, maniske lidelser, selvskading og hos emosjonelt ustabile.

Jeg anbefaler boken til alle nysgjerrige som trives med å ha bein i flere leire - i biologien, i kulturen og i møter med mennesker.

\section{Medisinsk etikk for viderekomne}

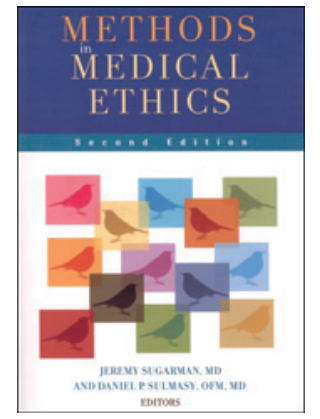
Jeremy Sugarman, Daniel P. Sulmasy, red.
Methods in medical ethics

2. utg. 353 s, tab, ill. Washington, DC: Georgetown University Press, 2010.

Pris USD 40

ISBN 978-1-58901-701-6

I løpet av 2011 ble det trykt mer enn 500 avisartikler om «tidlig ultralyd» i Norge. Lysten til å debattere medisinsketiske temaer er til tider stor i den norske offentligheten - med mange bidragsytere. Hva skiller så den medisinske etikken, som fag, fra en hvilken som helst meningsytrer? Hva består den eventuelle «fagligheten» i?

Som det fremgår av tittelen, ligger svaret i metoden. I likhet med forskning i sin alminnelighet henter etikkforskningen sin autoritet fra en metodisk tilnærming til et problem. Men ulikt forskning i sin alminnelighet, hersker det liten eller ingen enighet om den korrekte metodiske tilnærmingen til medisinsk etikk.

Ti år etter førsteutgaven har Jeremy Sugarman og Daniel Sulmasy samlet noen av verdens fremste etikere til en ny gjennomgang av de ulike metodiske tilnærmingene i fagfeltet medisinsk etikk. Resultatet er en spennende innføring i temaer som kasuistikk, allmennmoral og prinsippbasert etikk.

Videre drøfter bidragsyterne forholdet mellom medisinsk etikk på den ene siden og historie, litteratur, sosiologi og religion på den andre. Og sist, men ikke minst, vies mye plass til den empiriske etikken. Empiriske tilnærminger er den raskest voksende delen av fagfeltet medisinsk etikk. Metodikken er velkjent fra mange andre fagfelt, og empiriske tilnærminger tilfører sånn sett den medisinske etikken autoritet. Man gjør fagfeltet vitenskapelig. Samtidig vil alltid empiriske tilnærminger stå $i$ et spenningsforhold til den medisinske etikkens normative ambisjon. Man kommer som kjent ikke automatisk fra «er til bør» uten å begå en feilslutning. Dermed blir metodediskusjonen i medisinsk etikk en vedvarende og integrert del av faget.

Methods in medical ethics slutter imidlertid ikke med bare å påvise de mange, og til tider spenningsfylte, tilnærmingene til medisinsk etikk. I et nyskrevet sluttkapittel om behandlingsavgjørelser ved livsforlengende behandling for inkompetente pasienter, gjennomgår forfatterne 40 år med medisinsk fagetisk tilnærming til feltet. Hensikt med dette kapitlet er ikke så mye å oppsummere litteraturens konklusjoner som det er å beskrive en rekke av de ulike metodiske tilnærmingene som etikere har møtt problemet med gjennom årene. Men konklusjonen er optimistisk: Metodepluralisme bringer fagetikken videre og gjør den medisinske etikken interessant og relevant både i og utenfor klinikken.

Dette er ikke som enhver annen metodebok i vitenskapen. Boken er grunnleggende filosofisk orientert fordi forfatterne hele tiden beskriver et fagfelt som ofte ikke gjenkjennes som et fag, eller som kan tenkes å ha en «metode» i klassisk forstand. Den er spennende fra første til siste side, men kanskje primært for dem med en viderekommen interesse for medisinsk etikk.

Leseren får en forståelse for hvorfor medisinsk etikk både er noe alle kan ha en formening om, samtidig som systematisk tilnærming er mulig og nødvendig.

\section{Berge Solberg}

Institutt for samfunnsmedisin

Norges teknisk-naturvitenskapelige universitet 